\title{
SYNTHESIS AND APPLICATIONS OF NANO TITANIA PARTICLES: A REVIEW
}

\author{
A. Khitab1, S. Ahmad1,2, M.J. Munir'3, S.M.S. Kazmi' ${ }^{3}$, T. Arshad1 \\ and R.A. Khushnood ${ }^{2,4}$ \\ ${ }^{1}$ Dept. of Civil Engineering, Mirpur University of Science \& Technology, Mirpur AJK, Pakistan \\ 2Dept. of Structural, Geotechnical \& Building Engineering, Politecnico di Torino, Turin, Italy \\ ${ }^{3}$ Dept. of Civil Engineering, Royal Melbourne Institute of Technology, Melbourne, Australia \\ ${ }^{4}$ NUST Institute of Civil Engineering, National University of Sciences \& Technology, Islamabad, Pakistan
}

Received: June 13, 2017

\begin{abstract}
This paper reviews the synthesis methods of nano titania particles and their utilization in various applications with concise discussion on the related health concerns. Owing to the efficient photocatalytic properties of nano titania particles along with high stability, super hydrophilicity and low cost, these particles are perfect candidate for the production for coatings on the surfaces of construction materials i.e. tiles, facades, wall etc. The nano titania coatings are capable of decomposing dust, dirt and organic pollutants in the presence of sunlight. These decomposed products may then easily be washed away by rinsing thus providing easy cleaning and keeps the buildings in younger or fresh look for decades.
\end{abstract}

\section{INTRODUCTION}

Self-cleaning coatings have drawn great interest due to their potential application in many fields of life [1]. The surface cleaning of different building parts like tiles, facades and glass-panes causes an extensive use of energy and costs, which can be minimized to a great extent by using self-cleaning surfaces [2-4]. Two techniques are used to make selfcleaning material surfaces i.e. the development of super-hydrophobic or super-hydrophilic surfaces [3]. Super-hydrophobic surfaces are tremendously repellent to water, owing to a low surface energy of material [5]. In nature, lotus leaves have super-hydrophobic surfaces owing to their waxy low surface energy nature. Whereas, super-hydrophilic surfaces absorb water very quickly e.g. paper, sponges, textiles etc. [2-7]. In construction industry, roads and highways possess very large surface areas that may be modified to get benefits from the self-cleaning and photocatalytic properties of nano titania parti- cles (NTPs) [8-10]. In the subsequent paras, a brief discussion on the synthesis methodologies of NTPs and afterwards their mechanism of action and applications is provided.

\section{SYNTHESIS OF NANO TITANIA PARTICLES (NTPS)}

Owning to the potential benefit of NTPs, researchers have investigated vastly the methods for the synthesis and production of nano/micro- $\mathrm{TiO}_{2}$ structures. Following is a concise summary of methods employed for the synthesis of NTPs.

\subsection{Aqueous sol-gel method}

The sol-gel method is very famous in materials science for the synthesis of versatile types of materials. In the sol-gel process, a solution is prepared from titanium precursors and suitable solvents. The reactions of hydrolysis and polymerization take Corresponding author: S. Ahmad, e-mail: sajjad.ahmad@polito.it 


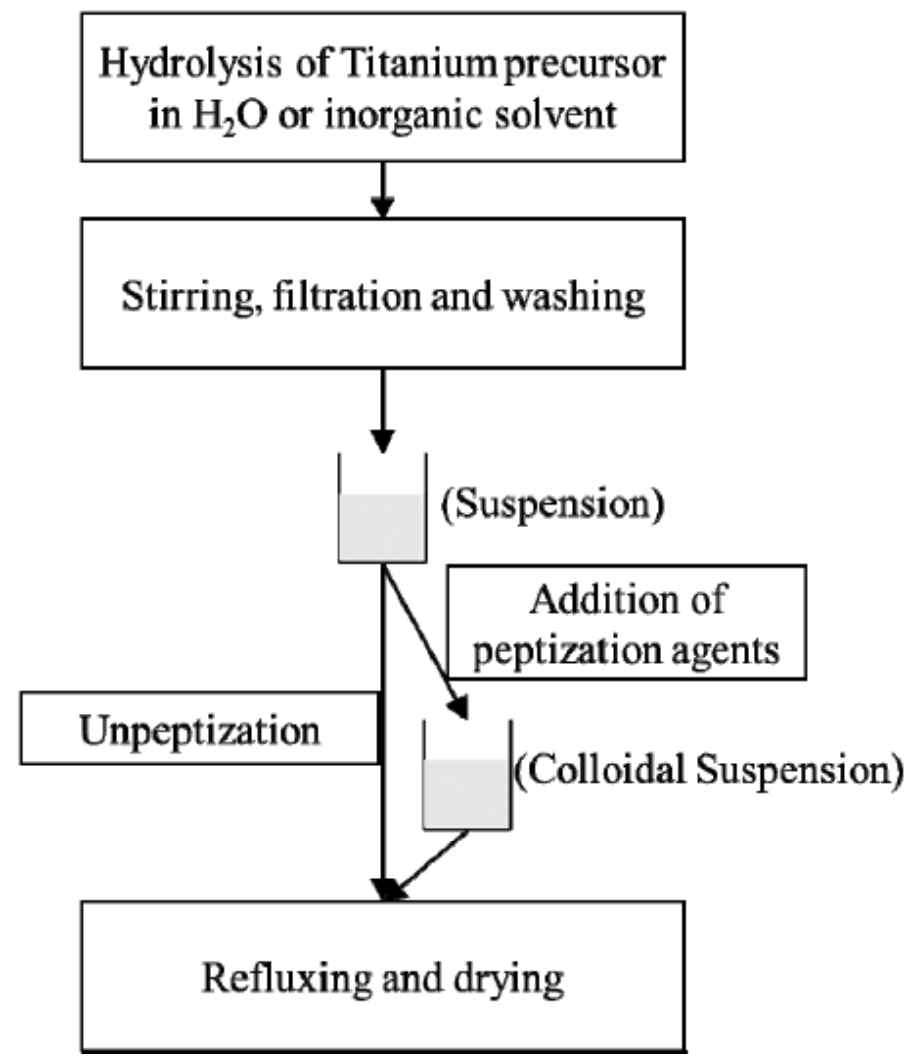

Fig. 1. Typical sol-gel methodology for the synthesis of NTPs, reprinted with permission from S. Winardi, R.R. Mukti, K.N.P. Kumar, J. Wang, W. Wunderlich and T. Okubo // Langmuir. 26 (2010) 4567, (c) 2010 American Chemical Society.

place in the solution thus converting the solution in to suspension form. In the suspension during the polymerization process the solvents evaporates leading to the formation of gel like structures. The produced gel may be cast into solid shapes, thin films or coatings and their further heat treatment transforms the gel into a dense and hard material [11-20]. The sol-gel method is so versatile that by controlling the reaction parameters various products ranging from aerogels to ceramic fibers and solid castables to ultrafine powders may be produced $[16,17,21-24]$. Titania nano particles have been synthesized using various precursors, solvents, catalysts, peptizing and complexing agents under different temperature and aging conditions $[17,25,26]$. Typical methodology adopted for the synthesis of NTPs via sol-gel process is presented in Fig. 1 [27].

In the sol-gel process, the peptizing agents charge the solution particles therefore; the electrostatic repulsion among them produces a uniform colloidal suspension without aggregation thus producing smaller size particles in densely packed gel, while in un-peptized solution aggregation starts leading to the larger particle sizes. The particle size and their packing strongly influence the anatase to rutile phase transformation as indicated by Winardi et al. (Fig. 2) [27]. In the sol-gel process, the molar ratio of water to precursor $(\mathrm{W} / \mathrm{P})$ is directly related to the sizes of the titania grains produced and also the small grains produced at lower W/P exhibit lower transformation temperature from anatase to rutile phase. It has been reported that the heat treatment of titania particles increase the particle sizes as well as transformation from anatase to rutile phase but if some dopant (aluminum, tin or iron) are used during the synthesis then the grains sizes during heat treatment do not grow substantially as compared to the undoped sample [26]. Besides powder synthesis, sol-gel process may be used to coat other materials with layers of NTPs as Barmala et al. reported the deposition of thin film and small buds of titania on the surface of MWCNTs when they are added into the hydrolyzed solution of Tetraethyl orthotitanate (TEOT) and isopropanol [28]. The coating formation on multi walled carbon nanotubes (MWCNTs) increase the surface area of NTPs enormously thus enhancing the photocatalytic efficiency of the NTPs-MWCNTs composite [28].

\subsection{Non-aqueous sol-gel method}

The sol-gel method may provide better control over the rate of reactions if non-aqueous solvents are 


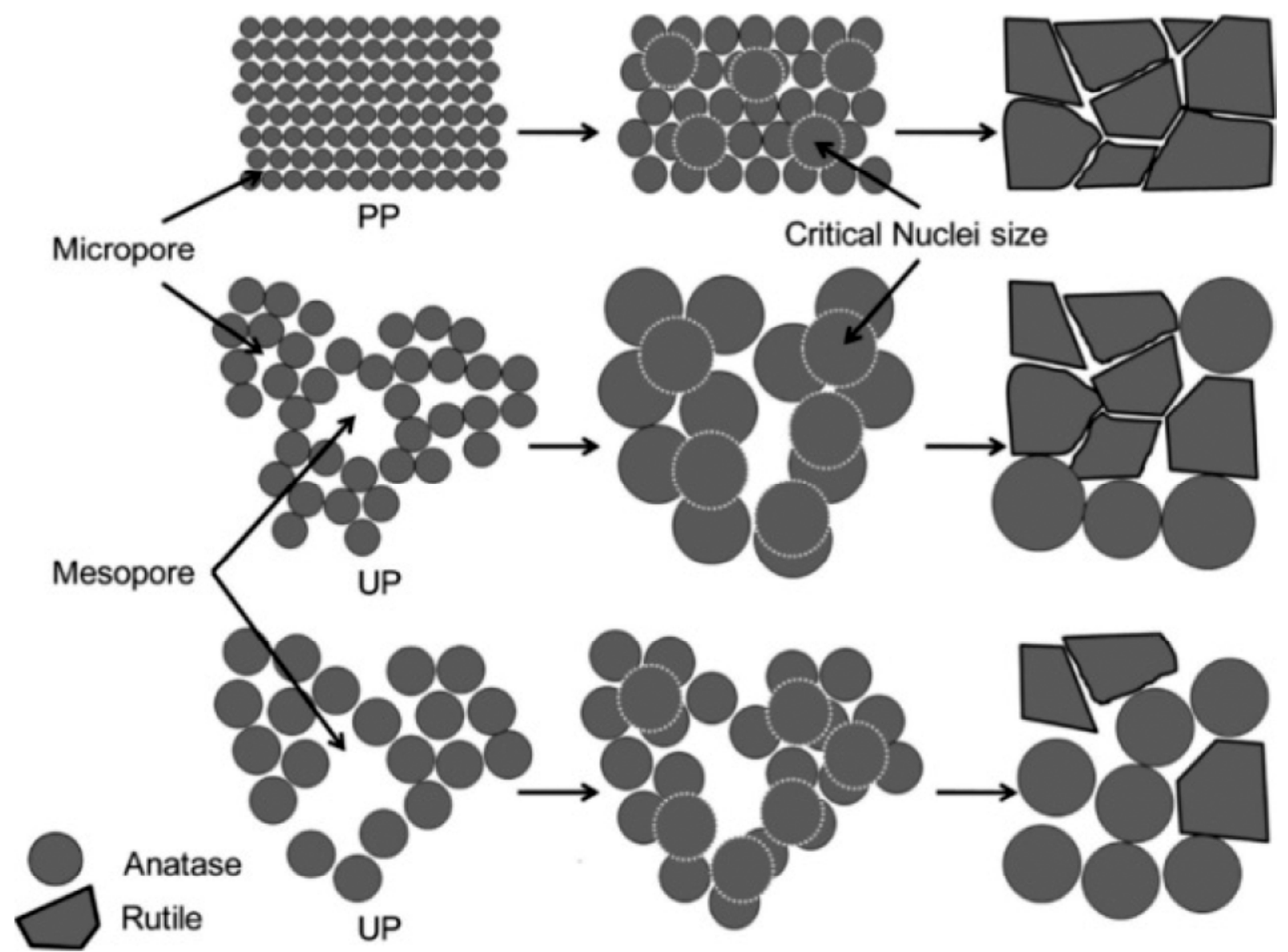

Fig. 2. Influence of peptization on the anatase to rutile phase transformation, reprinted with permission from S. Winardi, R.R. Mukti, K.N.P. Kumar, J. Wang, W. Wunderlich and T. Okubo // Langmuir. 26 (2010) 4567, (c) 2010 American Chemical Society.

employed instead of water. In this type of synthesis, the hydrolysis and condensation reactions are much slower as compared to the aqueous sol-gel methods. The slow reactions rates enable the possibility to control over morphology and the size of the NTPs by tuning the reactivity of the precursors [26]. This method may be further be classified in to non-hydrolytic and non-aqueous methods. The prior one is based upon the formation of metal oxides by reaction of oxygen containing organic molecules such as organic ethers or metal alkoxide molecules without any involvement of the water molecules in the process, whereas in the later the water molecules are produced insitu and take part in the hydrolysis $[23,29,30]$. The synthesis of metal oxides from their chlorides such as titanium tetrachloride $\left(\mathrm{TiCl}_{4}\right)$, vanadium oxytrichloride $\left(\mathrm{VOCl}_{3}\right)$ and tungsten hexachloride $\left(\mathrm{WCl}_{6}\right)$ by using anhydrous benzyl alcohol was firstly reported by Niederberger et al. [31]. The non-aqueous sol-gel method of NTPs synthesis possesses advantage for producing very fine particles with pure crystalline (anatase) phase.
The particle sizes can be controlled by adjusting the amount of precursor, temperature and duration of aging for example lower amount of precursor in the solution produces smaller sized particles whereas higher ageing temperature results in larger particle sizes [32,33]. Another route of NTPs synthesis without any solvent is known as "ether route" in which the precursor and reactants are kept in closed vessels at higher above room temperature. The size and morphology of the developed particles are controlled by the reaction time, temperature and the quantity of precursor and reactant in the mixture [34].

\subsection{Hydrothermal and solvothermal method}

The photocatalytic activity of the NTPs strongly depends upon their size e.g. NTPs having sizes around $10 \mathrm{~nm}$ exhibit much higher rate of photocatalytic action [35,36]. In the sol-gel methods of NTPs, the usual size range of NPs is $20-50 \mathrm{~nm}$. 


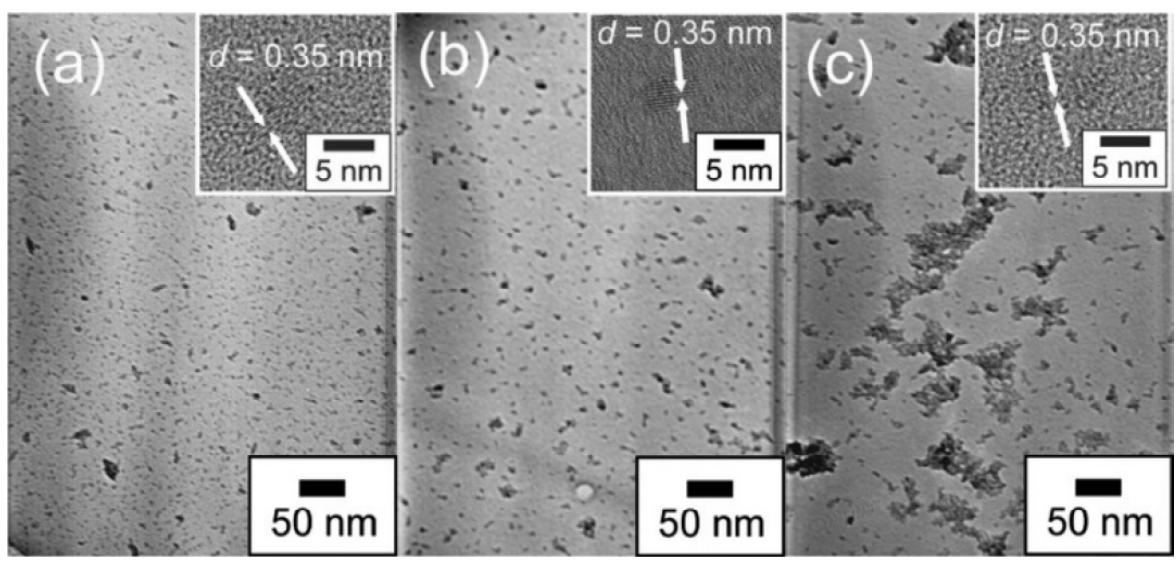

Fig. 3. FESEM micrographs of NTPs synthesis in hydrothermal process, heating at $80^{\circ} \mathrm{C}$ for (a) $30 \mathrm{~h}$, (2) $42 \mathrm{~h}$, (3) $70 \mathrm{~h}$, reprinted with permission from N. Watanabe, T. Kaneko, Y. Uchimaru, S. Yanagida, A. Yasumori and Y. Sugahara // CrystEngComm. 15 (2013) 10533, (c) 2013 Royal Society of Chemistry.

Therefore, to obtain the NTPs of very small size hydrothermal method may be employed. The hydrothermal method involves the heating of titanium precursors in peptized or un-peptized form under high temperature and pressures in teflon lined steel autoclaves. The temperature and pressures developed inside the autoclave during the synthesis process strongly depends upon the types and quantity of precursors and additives in the mix. Another advantage of hydrothermal process is that it can produce anatase phase particles in a single step if $\mathrm{HCl}$ is used and rutile phase particles in case of $\mathrm{HNO}_{3}$ as demonstrated by Wu et al. They treated a solution of Tetrabutyl titanate (TBT), $\mathrm{HCl}$ and water in a teflon lined vessel for $10 \mathrm{~h}$ at $220^{\circ} \mathrm{C}$ and synthesized anatase phase particles having average diameter of $10 \mathrm{~nm}$ [37]. Watanabe etal. observed that the size of titania particles depends upon the residence time (at the specified temperature) of the precursor solution in the autoclave due to the agglomeration of particles with the passage of time (Fig. 3) [38].

Solvothermal method of NTPs particles synthesis is similar to the hydrothermal except in this procedure water is not utilized in the reaction. The nonaqueous nature of these methods allows the synthesis at even higher temperature and pressure conditions by selecting suitable inorganic solvents having high boiling points and vapor pressures [39]. Wu et al. used the solvothermal process and produced single phase anatase crystals at lower molar ratio of $\mathrm{TiCl}_{4}$ in the solution whereas rutile fibers at higher concentration of precursor [40]. Their observation about the dependence of particle size on the reaction temperature was in line with the results reported by Jensen and Neiderberger et al. [31-33,40].

\subsection{Micelle and reverse micelle method}

Micelles are the thermodynamically stable molecular assemblies of the surfactant molecules in a solution. The monomers form agglomerates when their concentrations exceed CMC (critical micelle concentration). In micelles, the monomers consist of hydrophilic heads with long hydrophobic tail. In aqueous solutions, the monomers align themselves into circular micelles with their hydrophobic tails in the center. This aggregation pattern reverse in case of non-polar organic solution and they are referred as inverse or reverse micelles. The shapes of micelles are usually spiral, but also form other shapes depending upon their packing parameters for example surfactant types and their concentrations in the solution [41-45]. Previously, the process of reverse micelles formation has been used for the synthesis of nano, micro and macro sized inorganic particles with effective control on their size and morphology. Besides particles nanowires of $\mathrm{BaCO}_{3}$ have been synthesized having length of about $100 \mu \mathrm{m}$ and diameter in the range of $10-30 \mathrm{~nm}$ [46]. In reverse micelle method of NTPs synthesis, Sakai et al. reported that the size of NTPs show strong dependence upon the concentration of surfactant molecules in the solution and their size reduces with the increase in the surfactant (Aerosol OT) quantity in the solution [47]. Besides smaller particle sizes at higher concentration of surfactants in solutions produces crystalline phases of anatase or rutile because the surfactant molecules slows down the hydrolysis process therefore giving more time for crystallization [43]. The concentration of acid in the solution also affects the phase composition of the synthesized particles for example at critical con- 


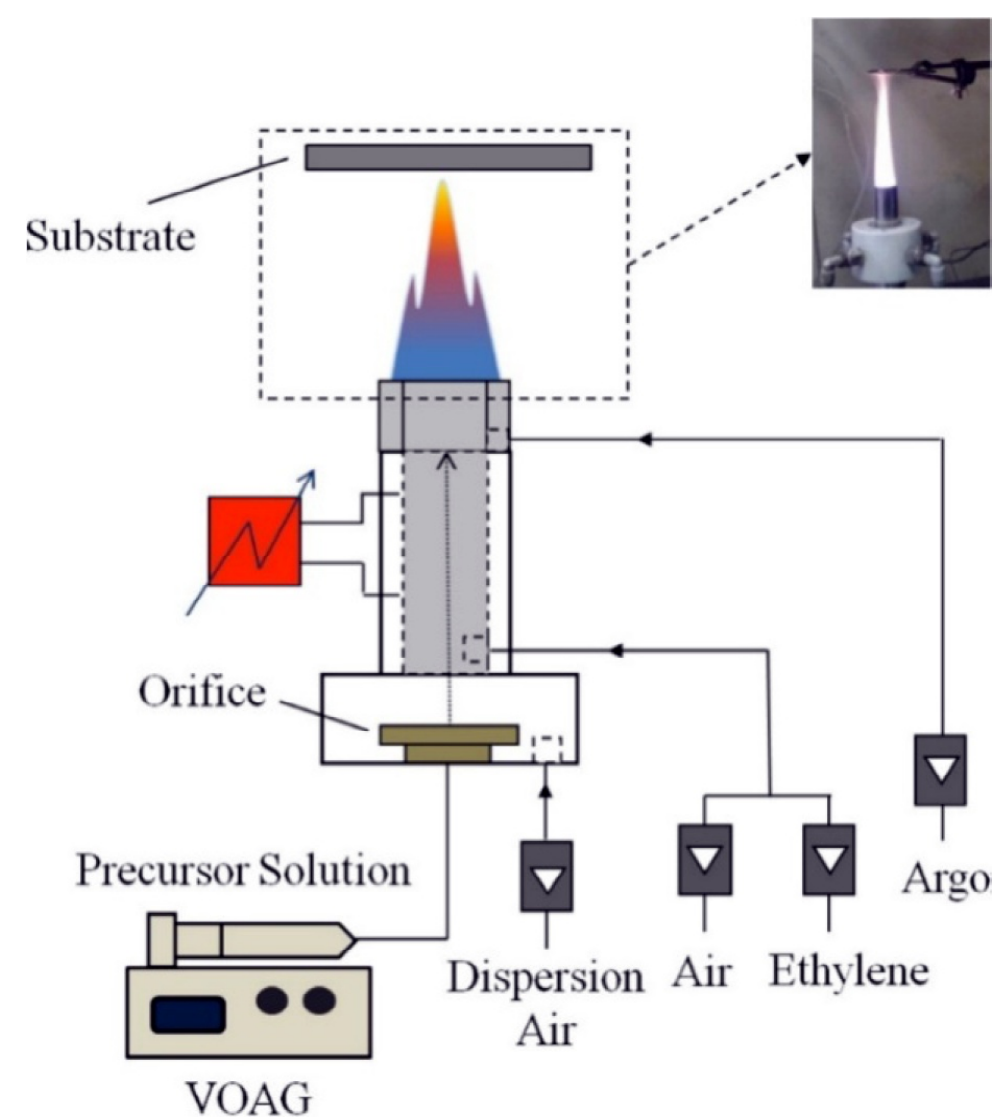

Fig. 4. Typical setup of aerosol flame synthesis apparatus.

centration of acid (CCA) in the solution produces crystalline phases of anatase and rutile. The critical quantity of acid depends upon the reaction temperature and reaction media, for example Zhang et al. reported the CCA as $2.5 \mathrm{M}$ in TBT with cyclohexane and NP-5 (Igepal CO-520) whereas Wu et al. evaluated CCA as $1.5 \mathrm{M}$ of $\mathrm{HCl}$ in TBT, Triton $\mathrm{X}-100$ and $\mathrm{n}$-hexanol in the temperature range of $120^{\circ} \mathrm{C}$ for $12 \mathrm{~h}$ and $220^{\circ} \mathrm{C}$ for $10 \mathrm{~h}[37,48]$. Sharma et al. investigated the formation of micelle and reverse micelle on the fly ash (FA) core [49]. In the process of micelle formation the sulfate anion of the SDS molecule interact with the FA core shell forming a hydrocarbon chain extending outwards [50]. The titania molecules attracted toward the core shell due to electrostatic potential forming micelles. While in case of using nonionic solution such as Triton X100 reverse micelle form around the FA core shell in the presence of $\mathrm{HCl}$ in the solution as $\mathrm{HCl}$ promotes the binding of proton through hydrogen bonding of the Triton X-100 around the core shell [51].

\subsection{Aerosol flame synthesis}

In this type of synthesis, the titanium precursor solutions are exposed to high temperature flumes and due to high temperature, the titanium molecules react with oxygen to produce NTPs. These particles can be directly deposited as a coating on the solid material sheets or ceramics etc. [52-55]. The typical aerosol flame synthesis setup consists of an aerosol generator and a burner as shown in Fig. 4. The flame coming from the burner is usually stabilized by using ceramic honeycombs. The flame is isolated from the surrounding air with the help of the flow of inert gas around the flame. Falco et al. utilized a TTIP precursor mixed with ethanol to produce NTPs nano particles in the size range of 27$30 \mathrm{~nm}$. The produced phases majorly consisted of rutile because the temperature in the ethylene flame during synthesis may reach up to $1700^{\circ} \mathrm{C}$ [56].

Liberini et al. reported that if the concentration of titanium precursor is reduced and synthesis is carried out in lean fuel flame (low temperature as compared to previous one i.e. $1350^{\circ} \mathrm{C}$ ) then the dominant phase produced is anatase [53,54]. The same phenomena was reported by Makela et al. as shown in Fig. 5 [55].

\subsection{Biosynthesis method}

This type of synthesis method involves microorganisms such as bacteria (Bacillus subtilis, Lactobacillus sp., Klebsiella pneumonia, Enterobacteria, E. 

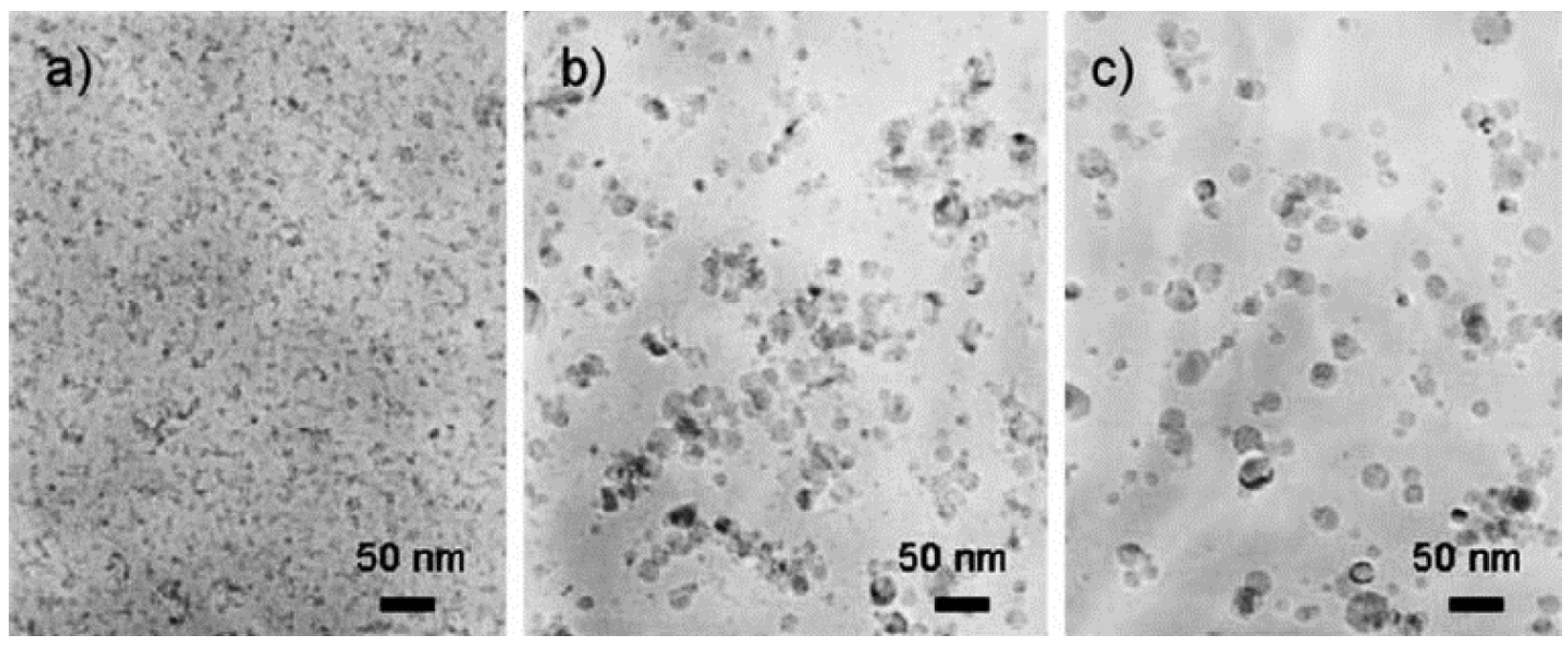

Fig. 5. Micrographs of NTPs deposited on steel substrate with titanium precursor mass flows in flame: (a) $11 \mathrm{mg} / \mathrm{min}$, (b) $240 \mathrm{mg} / \mathrm{min}$ and (c) $690 \mathrm{mg} / \mathrm{min}$, reprinted with permission from J.M. Mäkelä, S. Hellstén, J. Silvonen, M. Vippola, E. Levänen and T. Mäntylä // Mater. Lett. 60 (2006) 530, (c) 2005 Elsevier.

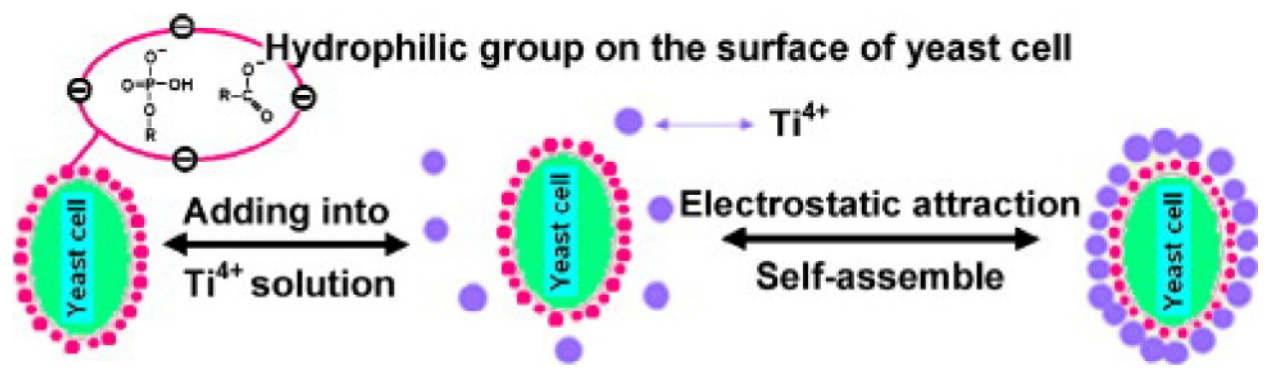

Fig. 6. Typical biosynthesis process of NTPs formation involving yeast cells, reprinted with permission from J. Cui, W. He, H. Liu, S. Liao and Y. Yue // Colloids Surfaces B Biointerfaces. 74 (2009) 274, (c) 2009 Elsevier.

coli, plectonema boryanum), yeast (Saccharomyces cerevisiae, Schizosaccharomyces pombe, Yarrowia lipolytica), fungi (Fusarium oxysporum, Verticillium, Helminthosporum solani, Penicillium fellutanum, Hormoconis resinae, Trichoderma reesei) etc. [57-67]. The biosynthesis methods are inexpensive, eco-friendly, scalable, reproducible and non-hazardous. They also do not require toxic substances nor produce harmful byproducts $[68,69]$. Literature indicates successful application of this method for the synthesis of metal and inorganic nano/micro particles such as gold, silver, CdS, palladium, $\mathrm{TiO}_{2}, \mathrm{Sb}_{2} \mathrm{O}_{3}$, etc.). In the synthesis procedure, the characteristics of the products depends upon the growth of microorganisms and the reaction environment like temperature, $\mathrm{pH}$, minerals and the solution media $[58,59,62-65,70]$. Therefore, the sizes and shapes of the particles synthesized by this method can be controlled by managing the reaction parameters mentioned above $[71,72]$. In biosynthesis, the bacteria exhibit strong negative electron potential and subsequently attracts the cations from the solution leading to the processes of hydrolysis and condensation. In yeasts their membrane (oxidoreductases) activates oxidase at lower $\mathrm{pH}$ levels and reductase at higher $\mathrm{pH}$ therefore causing the oxidation/reduction process in the biosynthesis whereas fungi are reported to release reducing agents causing the reduction reaction of the ions in the solution as shown in Fig. 6 [71-73]. Bansal et al. reported the synthesis of NTPs by using potassium fluotitanate $\left(\mathrm{K}_{2} \mathrm{TiF}_{6}\right)$ as precursor and fusarium oxyporum. The $\mathrm{TiF}_{6}^{-2}$ and the fungi reacted and due the hydrolysis reaction the NTPs were produced [74]. A brief summary of the synthesis of NTPs via methods mentioned above is presented in Table 1.

\section{MECHANISM OF PHOTO- CATALYSIS OF NTPS}

Catalyst is a substance that accelerates a chemical reaction without being consumed. Photo-catalysis is the acceleration of a chemical reaction by a catalyst in the presence of light [75]. The idea of application of photo-catalysis to environmental 
Table 1. Summary of NTPs synthesis methods.

\begin{tabular}{|c|c|c|c|c|c|}
\hline \multicolumn{6}{|c|}{ Synthesis method: Sol-gel method } \\
\hline $\begin{array}{l}\text { Titanium } \\
\text { precursor }\end{array}$ & $\begin{array}{l}\text { Solvent, } \\
\text { Surfactants \& } \\
\text { additives }\end{array}$ & Mechanism & Product morphology & $\begin{array}{l}\text { Crystal } \\
\text { phases }\end{array}$ & Ref. \\
\hline TTIP & $\begin{array}{l}\text { Isopropanol, } \\
\mathrm{H}_{2} \mathrm{O} \text { and } \\
\mathrm{HNO}_{3}\end{array}$ & $\begin{array}{l}\text { Peptized solution heated } \\
\text { for } 12 \mathrm{~h} \text { at } 80^{\circ} \mathrm{C} \text { and dried } \\
\text { at } 40^{\circ} \mathrm{C}\end{array}$ & $\begin{array}{l}\text { Avg. Particle size } 4.53 \\
\mathrm{~nm}\end{array}$ & Anatase & [27] \\
\hline TEOT & $\begin{array}{l}\text { Isopropanol, } \\
\mathrm{H}_{2} \mathrm{O} \text { and } \\
\mathrm{HNO}_{3}\end{array}$ & $\begin{array}{l}\text { TEOT and alcohol mixture } \\
\text { was stirred for } 0.5 \mathrm{~h} \text { and } \\
\text { then } \mathrm{HNO}_{3} \text { was added. } \\
\mathrm{MWCNTs} \text { added and } \\
\text { stirred for } 3 \mathrm{~h} \text { and dried af- } \\
\text { ter } 48 \mathrm{~h}\end{array}$ & $\begin{array}{l}\text { Coating and bud for- } \\
\text { mation on MWCNTs }\end{array}$ & - & [28] \\
\hline TBT & $\begin{array}{l}\mathrm{EtOH}, \mathrm{H}_{2} \mathrm{O} \\
\mathrm{HCl} \text { or AA }\end{array}$ & $\begin{array}{l}\text { The gel was prepared at } \\
\text { room temperature and } \\
\text { dried in vacuum at } 60^{\circ} \mathrm{C} \\
\text { for } 5 \mathrm{~h}\end{array}$ & $\begin{array}{l}\text { Avg. Particle size } 8.7 \\
\mathrm{~nm} \text { (fresh) } 13.9 \mathrm{~nm} \text { af- } \\
\text { ter } 1 \text { y ageing }\end{array}$ & Anatase & [26] \\
\hline TBT & $\begin{array}{l}\text { Ethylene gly- } \\
\text { col, acetone }\end{array}$ & $\begin{array}{l}\text { TBT and EG slotion was } \\
\text { stirred for } 8 \mathrm{~h} \text { then acetone } \\
\text { added. After } 2 \mathrm{~h} \text { the TiO2 } \\
\text { particles were separated } \\
\text { by centrifugation }\end{array}$ & $\begin{array}{l}203 \mathrm{~nm} \text { without water } \\
\text { addition and } 67 \mathrm{~nm} \\
\text { with water/TBT ratio } \\
(\mathrm{v} / \mathrm{v}) \text { of } 50: 1\end{array}$ & $\begin{array}{l}\text { Anatase and } \\
\text { rutile }\end{array}$ & [123] \\
\hline TTIP & $\begin{array}{l}\text { Malonic Acid, } \\
\text { Acetic acid, } \\
\text { Nitric acid Tri- } \\
\text { ethylamine }\end{array}$ & $\begin{array}{l}\text { TTIP and acetic or malonic } \\
\text { acid solution was stirred } \\
\text { for } 30 \text { min then refluxing } \\
\text { for } 3 \mathrm{~h} \text { at } 100^{\circ} \mathrm{C} \text {. }\end{array}$ & $\begin{array}{l}\text { Avg. Particle size } 52 \\
\mathrm{~nm}\end{array}$ & $\begin{array}{l}\text { Anatase with } \\
\text { few traces of } \\
\text { brookite }\end{array}$ & [25] \\
\hline \multicolumn{6}{|c|}{ Synthesis method: Non-aqueous sol-gel method } \\
\hline $\begin{array}{l}\text { Titanium } \\
\text { precursor }\end{array}$ & $\begin{array}{l}\text { Solvent/reac- } \\
\text { tants }\end{array}$ & Mechanism & Product morphology & $\begin{array}{l}\text { Crystal } \\
\text { phases }\end{array}$ & Ref. \\
\hline $\mathrm{TiCl}_{4}$ & $\begin{array}{l}\text { Anhydrous } \\
\text { benzyl alco- } \\
\text { hol }\end{array}$ & $\begin{array}{l}\mathrm{TiCl} 4 \text { and benzyl solution } \\
\text { was prepared at } 40^{\circ} \mathrm{C} \text { with } \\
\text { continuous stirring. Aging } \\
\text { was done for } 7-21 \text { days at } \\
40^{\circ} \mathrm{C}\end{array}$ & $\begin{array}{l}\text { Particle size } 4-8 \mathrm{~nm} \text {, } \\
\text { after calcination } 13-20 \\
\mathrm{~nm}\end{array}$ & Anatase & [32] \\
\hline $\mathrm{TiCl}_{4}$ & $\begin{array}{l}\text { Diisopropyl } \\
\text { ether, dichlo- } \\
\text { romethane }\end{array}$ & $\begin{array}{l}\text { Mixture of } \mathrm{TiCl}_{4} \text { and reac- } \\
\text { tants was kept in pyrix } \\
\text { tube at } 80^{\circ} \mathrm{C} \text { for } 60 \mathrm{~h}\end{array}$ & Particle size $4-15 \mathrm{~nm}$ & $80 \%$ anatase & [34] \\
\hline $\mathrm{TiCl}_{4}$ & $\begin{array}{l}\text { Anhydrous } \\
\text { benzyl alco- } \\
\text { hol, ethanol }\end{array}$ & $\begin{array}{l}\mathrm{TiCl}_{4} \text { and ethanol solution } \\
\text { was prepared then benzyl } \\
\text { was added with continu- } \\
\text { ous stirring. Aging was } \\
\text { done for } 20 \text { and } 45 \text { h at } 80 \\
{ }^{\circ} \mathrm{C}\end{array}$ & Particle size 3-7 nm & Anatase & [33] \\
\hline $\mathrm{TiCl} 4$ & Acetone & $\begin{array}{l}\text { Solution was prepared and } \\
\text { heated in sealed teflon } \\
\text { vessel for } 12 \mathrm{~h} \text { at } 80-140 \\
{ }^{\circ} \mathrm{C}\end{array}$ & Particle size 4-10 nm & $\begin{array}{l}\text { Anatase at } \\
\text { lower } \mathrm{TiCl}_{4} \\
\text { concentration } \\
\text { Rutile fibers at } \\
\text { higher } \mathrm{TiCl}_{4} \\
\text { concentration }\end{array}$ & [40] \\
\hline
\end{tabular}


Synthesis method: Hydrothermal and solvothermal method

\begin{tabular}{|c|c|c|c|c|c|}
\hline $\begin{array}{l}\text { Titanium } \\
\text { precursor }\end{array}$ & $\begin{array}{l}\text { Surfactants \& } \\
\text { additives }\end{array}$ & Mechanism & Product morphology & $\begin{array}{l}\text { Crystal } \\
\text { phases }\end{array}$ & Ref. \\
\hline TTIP & Isopropanol & $\begin{array}{l}\text { Calcination in furnace for } \\
1 \mathrm{~h} \text { at } 300^{\circ} \mathrm{C} \text { under atmos- } \\
\text { pheric pressure }\end{array}$ & $\begin{array}{l}\text { Avg. Particle size } 3.89 \\
\mathrm{~nm}\end{array}$ & Anatase & [36] \\
\hline TBT & $\mathrm{H}_{2} \mathrm{O}, \mathrm{HCl}$ & $\begin{array}{l}\text { Calcination of the solution } \\
\text { in closed teflon lined fur- } \\
\text { nace for } 10 \mathrm{~h} \text { at } 220^{\circ} \mathrm{C}\end{array}$ & $\begin{array}{l}\text { Avg. Particle size } 10 \\
\mathrm{~nm}\end{array}$ & Anatase & [37] \\
\hline $\mathrm{TiCl}_{4}$ & $\mathrm{CH}_{2} \mathrm{Cl}_{2}, \mathrm{UHP}$ & $\begin{array}{l}\text { Heating of solution in } \\
\text { closed teflon lined vessel } \\
\text { for } 30,42 \text { and } 70 \text { h at } 80 \\
{ }^{\circ} \mathrm{C}\end{array}$ & $\begin{array}{l}\text { Avg. partcle size } 5 \mathrm{~nm} \\
\text { for } 30 \mathrm{~h} \text { heating period }\end{array}$ & Anatase & [38] \\
\hline TBT & $\beta-\mathrm{CD}, \mathrm{NaOH}$ & $\begin{array}{l}\text { Solution of â-CD and } \mathrm{H}_{2} \mathrm{O} \\
\text { was prepared at } 60{ }^{\circ} \mathrm{C} \text {. } \\
\text { TBT was added dropwise } \\
\text { and homogenized for } 2 \mathrm{~h} \text {. } \\
\text { Heating of solution at } 150 \\
{ }^{\circ} \mathrm{C} \text { for } 48 \mathrm{~h} \text { in closed teflon } \\
\text { lined vessel }\end{array}$ & Particle size 9-16 nm & Anatase & [124] \\
\hline \multicolumn{6}{|c|}{ Synthesis method: Micelle and reverse micelle method } \\
\hline $\begin{array}{l}\text { Titanium } \\
\text { precursor }\end{array}$ & $\begin{array}{l}\text { Surfactants \& } \\
\text { additives }\end{array}$ & Mechanism & Product morphology & $\begin{array}{l}\text { Crystal } \\
\text { phases }\end{array}$ & Ref. \\
\hline TTIP & $\begin{array}{l}\text { SDS, Etha- } \\
\text { nol, Fly ash } \\
\text { as core shell }\end{array}$ & $\begin{array}{l}\text { Solution stirred for } 2 \mathrm{~h} \text { at } \\
\text { room temperature and } \\
\text { dried at } 50^{\circ} \mathrm{C}\end{array}$ & $\begin{array}{l}\text { 3-7 } \mathrm{nm} \text { coating of } \mathrm{TiO}_{2} \\
\text { on FA particles }\end{array}$ & Anatase & [49] \\
\hline TTIP & $\begin{array}{l}\text { Triton } \mathrm{X}-100, \\
\mathrm{HCl} \text {, Ethanol, } \\
\text { Fly ash as } \\
\text { core shell }\end{array}$ & $\begin{array}{l}\text { Solution stirred for } 2 \mathrm{~h} \text { at } \\
\text { room temperature and } \\
\text { dried at } 50^{\circ} \mathrm{C}\end{array}$ & $\begin{array}{l}\text { 3-7 } \mathrm{nm} \text { coating of } \mathrm{TiO}_{2} \\
\text { on } \mathrm{FA} \text { particles }\end{array}$ & $\begin{array}{l}{[101],[200]} \\
\text { Anatase[110], } \\
{[101],[211]} \\
\text { Rutile }\end{array}$ & [49] \\
\hline TTIP & $\begin{array}{l}\text { Aerosol OT, } \\
\text { Cyclohexane, } \\
\text { Alcohol (2- } \\
\text { propanol, 1- } \\
\text { butanol, 1- } \\
\text { pentanol) }\end{array}$ & $\begin{array}{l}\text { Aerosol OT mixed with } \\
\text { cyclohexane at } 30{ }^{\circ} \mathrm{C} \text { for } \\
\text { micelle formation then ad- } \\
\text { dition of TTIP and alcohol } \\
\text { for } \mathrm{TiO}_{2} \text { particles synthe- } \\
\text { sis }\end{array}$ & $\begin{array}{l}16 \mathrm{~nm} \text { for } 10 \% \text { concen- } \\
\text { tration of Aerosol OT }\end{array}$ & $\begin{array}{l}\text { Synthesized } \\
\text { particles were } \\
\text { amorphous } \\
\text { but upon calci- } \\
\text { nation at } \\
500^{\circ} \mathrm{C} \text { trans- } \\
\text { formed into } \\
\text { Anatase }\end{array}$ & [47] \\
\hline TBT & $\begin{array}{l}\text { Cyclohexane, } \\
\text { NP-5(Igepal } \\
\text { CO-520), } \\
\text { HCL }\end{array}$ & $\begin{array}{l}\text { Precursor, solvent and } \\
\text { surfactant mixed by stir- } \\
\text { ring and standtime of } 20 \\
\text { day at RT }\end{array}$ & $\begin{array}{l}35-40 \mathrm{~nm} \text { width and } \\
150-160 \mathrm{~nm} \text { long shut- } \\
\text { tle like structure }\end{array}$ & $\begin{array}{l}\text { At CCA pure } \\
\text { rutile were ob- } \\
\text { served and at } \\
\text { low acid con- } \\
\text { centration } \\
\text { amorphous or } \\
\text { mixture with } \\
\text { anatase was } \\
\text { produced }\end{array}$ & [43] \\
\hline
\end{tabular}




\begin{tabular}{|c|c|c|c|c|c|}
\hline \multicolumn{6}{|c|}{ Synthesis method: Aerosol flame synthesis } \\
\hline $\begin{array}{l}\text { Titanium } \\
\text { precursor }\end{array}$ & Solvent & Mechanism & Product morphology & $\begin{array}{l}\text { Crystal } \\
\text { phases }\end{array}$ & Ref. \\
\hline TTIP & Ethanol & $\begin{array}{l}\text { The precursor was heated } \\
\text { at } 177^{\circ} \mathrm{C} \text { and introduced } \\
\text { into ethylene flame having } \\
\text { temp around } 1700^{\circ} \mathrm{C}\end{array}$ & $\begin{array}{l}\text { Observed particle size } \\
27-30 \mathrm{~nm}\end{array}$ & $\begin{array}{l}9-15 \% \text { ana- } \\
\text { tase and } 85- \\
95 \% \text { rutile }\end{array}$ & [56] \\
\hline TTIP & Ethanol & $\begin{array}{l}\text { The precursor was intro- } \\
\text { duced in the form of } 80 \mathrm{~nm} \\
\text { droplets into the ethylene } \\
\text { flame having temp around } \\
1350^{\circ} \mathrm{C} \text { and } \mathrm{TiO}_{2} \text { particles } \\
\text { were deposited on alu- } \\
\text { minium substrate }\end{array}$ & $\begin{array}{l}\text { Average particle size } \\
3.5 \mathrm{~nm}\end{array}$ & Anatase & [53] \\
\hline TEOT & Ethanol & $\begin{array}{l}\text { The solution was injected } \\
\text { in } \mathrm{H}_{2}-\mathrm{O}_{2} \text { flame having temp } \\
1100-1500{ }^{\circ} \mathrm{C} \text { and } \mathrm{TiO}_{2} \\
\text { particles were deposited } \\
\text { on steel substrate }\end{array}$ & $\begin{array}{l}\text { Deposited particle size } \\
\text { varied from 5-50 } \mathrm{nm} \\
\text { with the precursor flow } \\
\text { rate } 5-200 \mathrm{mg} / \mathrm{min}(11 \\
\mathrm{nm} \text { at } 23 \mathrm{mg} / \mathrm{min} \text { flow) }\end{array}$ & $\begin{array}{l}\text { Anatase at } \\
\text { low precursor } \\
\text { flow rate and } \\
\text { temp and } \\
\text { gradually } \\
\text { transformation } \\
\text { to rutile phase } \\
\text { with higher } \\
\text { flow rate and } \\
\text { temp }\end{array}$ & [55] \\
\hline TTIP & Acetonitrile & $\begin{array}{l}\text { The solution was intro- } \\
\text { duced into xylene-oxygen } \\
\text { flame }\end{array}$ & Particle size $25-30 \mathrm{~nm}$ & $\begin{array}{l}96 \% \text { anatase } \\
{[011] \text { in oxic }} \\
\text { flame and } 6 \% \\
\text { anatase in an- } \\
\text { oxic flame }\end{array}$ & [54] \\
\hline \multicolumn{6}{|c|}{ Synthesis method: Bio synthesis method } \\
\hline $\begin{array}{l}\text { Titanium } \\
\text { precursor }\end{array}$ & $\begin{array}{l}\text { Microorgan- } \\
\text { isms }\end{array}$ & Mechanism & Product morphology & $\begin{array}{l}\text { Crystal } \\
\text { phases }\end{array}$ & Ref. \\
\hline $\mathrm{TiO}(\mathrm{OH})_{2}$ & $\begin{array}{l}\text { Lactobacillus } \\
\text { sp. }\end{array}$ & $\begin{array}{l}\text { Culture was grown for } 36 \\
\mathrm{~h} \text { in carbon and nitrogen } \\
\text { solution. } \mathrm{TiO}(\mathrm{OH})_{2} \text { added } \\
\text { to diluted culture and } \\
\text { heated at } 60{ }^{\circ} \mathrm{C} \text { for } 10- \\
20 \mathrm{~min} \text { and kept at } \mathrm{RT} \text { for } \\
12-48 \mathrm{~h}\end{array}$ & $\begin{array}{l}\text { Avg. particle size } 24 \\
\mathrm{~nm}\end{array}$ & $\begin{array}{l}\text { Anatase and } \\
\text { rutile }\end{array}$ & [71] \\
\hline $\mathrm{TiO}(\mathrm{OH})_{2}$ & $\begin{array}{l}\text { Sachharomy- } \\
\text { ces cerevisae }\end{array}$ & $\begin{array}{l}\text { Culture was grown for } 36 \\
\mathrm{~h} \text { in carbon and nitrogen } \\
\text { solution. } \mathrm{TiO}(\mathrm{OH})_{2} \text { added } \\
\text { to diluted culture and } \\
\text { heated at } 60^{\circ} \mathrm{C} \text { for } 10-20 \\
\text { min and kept at } \mathrm{RT} \text { for } 12- \\
48 \mathrm{~h}\end{array}$ & $\begin{array}{l}\text { Avg. particle size } 12 \\
\mathrm{~nm}\end{array}$ & $\begin{array}{l}\text { Anatase and } \\
\text { rutile }\end{array}$ & [71] \\
\hline
\end{tabular}


$\begin{array}{ll}\mathrm{K}_{2} \mathrm{TiF}_{6} & \begin{array}{l}\text { Fusarium } \\ \text { oxyporum }\end{array}\end{array}$

Culture was grown for 72

$\mathrm{h}$ in MGYP. $\mathrm{K}_{2} \mathrm{TiF}_{6}$ added

to diluted culture and kept

at $\mathrm{RT}$ for $24 \mathrm{~h}$
Avg. particle size 10 Rutile and

$[74]$

$\mathrm{nm} \quad$ brookite

\footnotetext{
AA - Acetylacetone $\mathrm{C}_{5} \mathrm{H}_{8} \mathrm{O}_{2}$; AIP - Aluminium isopropoxide; CCA - critical concentration of acid; EtOH Anhydrous ethanol; FA - Fly ash; FO - Ferric oxide; MWCNTs - Multi wall carbon nano tubes; NPs - Nano particles; NTPs - Nano titania particles; SDS - Sodium dodecyl sulfate; TBT - Tetrabutyl titanate Ti $(O-B u)_{4}$ or (Titanium tetra butoxide); TEOT - Tetraethyl orthotitanate or Titanium (IV) ethoxide Ti $\left(\mathrm{OC}_{2} \mathrm{H}_{5}\right)_{4} ; \mathrm{TTCl}$ - Tin tetrachloride; TTIP - Titanium tetra isopropoxide $\mathrm{Ti}\left\{\mathrm{OCH}\left(\mathrm{CH}_{3}\right)_{2}\right\}_{4}$.
}

cleanup was given some three decades ago. Titania is found in three crystalline forms: anatase, brookite and rutile. Anatase is reported to exhibit the highest photocatalytic activity [4]. The schematic diagram of photo-catalysis activity is presented in Fig. 7. The light responsible for the photocatalytic effect lies in the Ultra Violet (UV) component of the sunlight spectra. UV is the short-wavelength light after the blue/violet portion of the electromagnetic spectrum (ems). Sun emits light at all the different wavelengths in ems, but it is ultraviolet waves that are responsible for causing sunburns. In the course of action, the NTPs absorb ultraviolet radiation from light and the electron of their valence band transfer into the excited state. The excess energy of this excited electron advances the electron to the conduction band, creating an electron-hole pair. The positive-hole of titanium dioxide breaks apart the water molecule to form hydrogen gas and hydroxyl radical. The negative-electron reacts with oxygen molecule to form superoxide anion. This cycle continues till light is available $[4,76]$.

$$
\begin{aligned}
& \mathrm{TiO}_{2}+h v \rightarrow h^{+}+\bar{e}, \\
& \mathrm{OH}^{-}+h^{+} \rightarrow \mathrm{OH},
\end{aligned}
$$

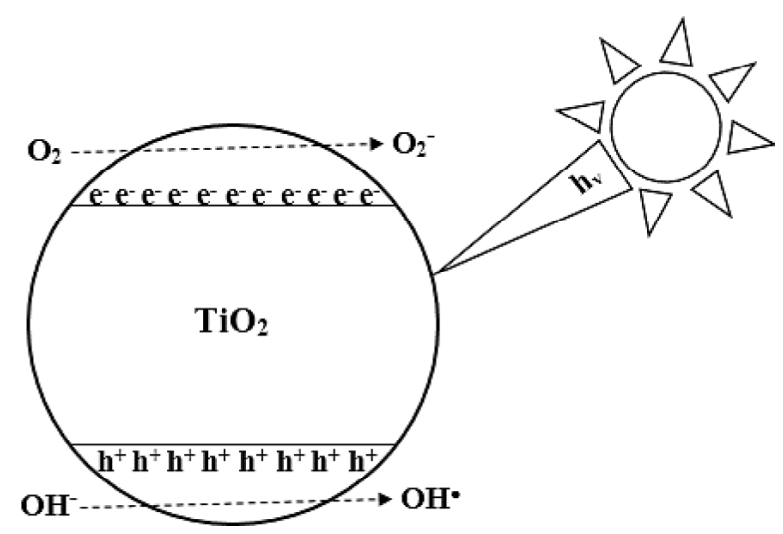

Fig. 7. Schematic diagram of photo-catalysis activity of NTPs.
$\mathrm{O}_{2}+\bar{e} \rightarrow \mathrm{O}_{2}^{-}$.

The hydroxyl and superoxide radicals are capable of decomposing various organic materials in contact with NTPs surface [75,77]. The airborne pollutant molecules are adsorbed on the NTPs surface and react with these radicals and decomposed. Ideally, the photocatalytic reaction leads to the formation of carbon dioxide $\left(\mathrm{CO}_{2}\right)$ and water $\left(\mathrm{H}_{2} \mathrm{O}\right)[75]$.

$\mathrm{C}_{x} \mathrm{H}_{2 x}+x \mathrm{O}_{2} \stackrel{\mathrm{TiO}_{2}+h v}{\longrightarrow} x \mathrm{CO}_{2}+\frac{x}{2} \mathrm{H}_{2}$.

\section{APPLICATIONS OF NTPS}

NTPs are one of the commonly used nano material around the globe (Fig. 8). Physically, it has no absorption in visible light; therefore, it has white color. Chemically, it is stable only in the dark. Its powder form is being used as white pigment since ancient times; it is abundantly available making it an inexpensive material [78]. Its production was approximately 2000 metric tons in 2005, 5000 metric tons in 2010 and expected to reach 10,000 metric tons by 2025 [79-81]. NTPs are mostly used as a white pigment due to its discoloration resistance, brightness and high refractive index; a high amount of NTPs (almost $70 \%$ of total generation) is used in paints and coatings [82]. Other items or industries like plastics, paper, textile, food, pharmaceuticals and toothpastes also include a considerable amount [69,83-85]. Some edible items like chocolates, candies and marshmallows also contain NTPs for white color, brightness and flavor [81]. The important industrial applications have also been summarized in Table 2. NTPs provide whitening effects to toothpastes [86]; it was approved as coloring agent in 2002, by food and drug administration (FDA) for use in toothpastes, chewing capsules and mouth fresheners [87]. To achieve improved photo stabilities, NTPs are added in cosmetics [88]. NTPs are considered as ultra-violent resistant material, 


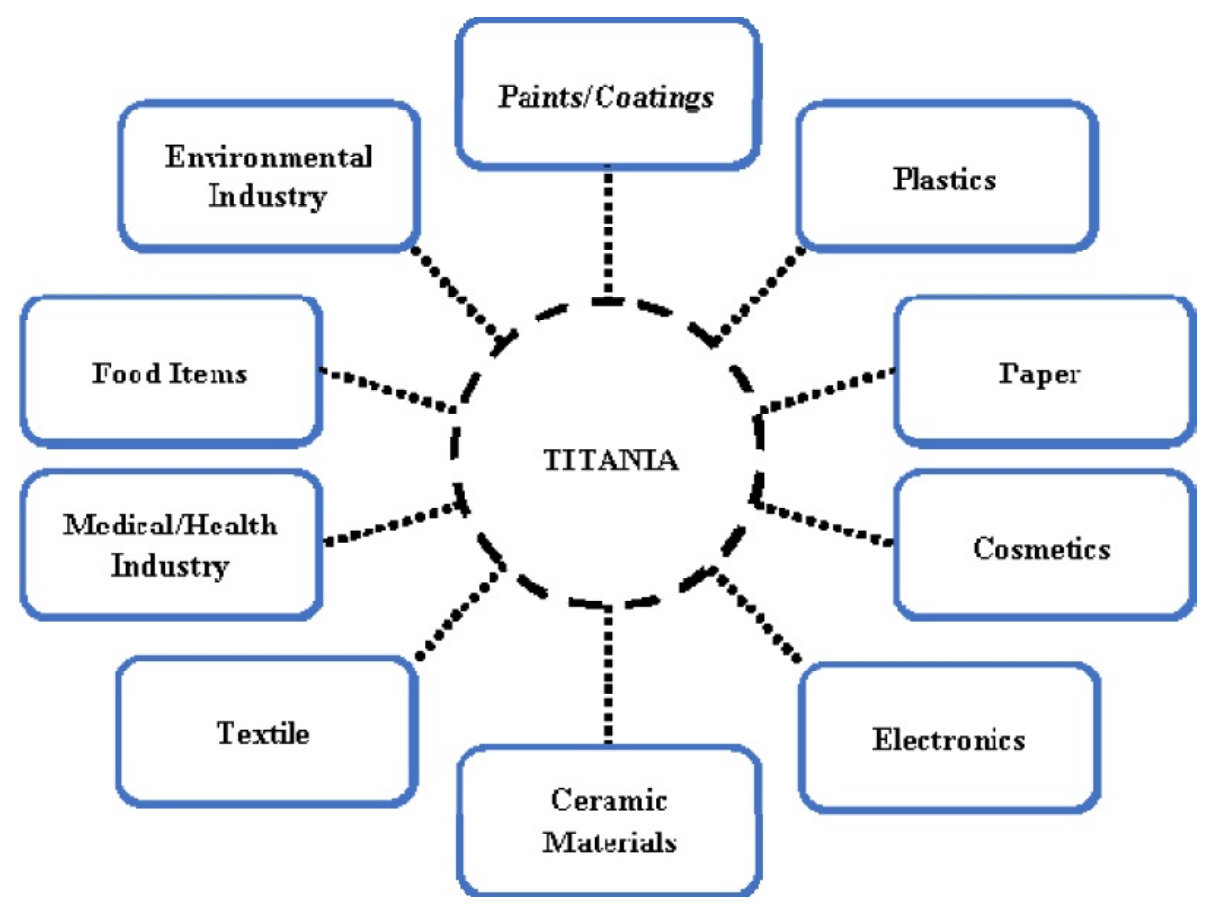

Fig. 8. Application areas of NTPs.

Table 2. Industrial applications of NTPs.

\begin{tabular}{|c|c|c|c|}
\hline Industry & Items & Reasons & Ref. \\
\hline $\begin{array}{l}\text { Paints/ Coat- } \\
\text { ings }\end{array}$ & Paints, varnishes and polishes & $\begin{array}{l}\text { Imparts whiteness, kills germs, exhibits } \\
\text { photo-catalysis. }\end{array}$ & {$[82,120]$} \\
\hline Polymer & Plastics & Provides whiteness, brightness and opacity. & $\begin{array}{l}{[69,81} \\
84,91]\end{array}$ \\
\hline Paper & Paper and packaging & Provides whiteness and opacity. & [89] \\
\hline Cosmetics & $\begin{array}{l}\text { Sun screens, whitening and } \\
\text { moisture protection creams, } \\
\text { makeup powder etc. }\end{array}$ & $\begin{array}{l}\text { Produces milky white color, provides resist- } \\
\text { ant to ultra-violet radiations and does not } \\
\text { discolor over a long period of time. }\end{array}$ & $\begin{array}{l}{[69,84} \\
88,120 \\
125]\end{array}$ \\
\hline Electronics & - & $\begin{array}{l}\text { Provides semiconductor properties, catalytic } \\
\text { activity, good electrochemical stability Has } \\
\text { high dielectric constant and resistance. }\end{array}$ & {$[92,109]$} \\
\hline $\begin{array}{l}\text { Construction } \\
\text { Materials }\end{array}$ & Ceramic materials & $\begin{array}{l}\text { Provides thermal stability and acid resistance, } \\
\text { having high melting point and high refractive } \\
\text { index. }\end{array}$ & [81] \\
\hline Textile & All types of cloth & $\begin{array}{l}\text { Provides self-cleaning property, wettability, } \\
\text { ultra-violet radiations protection, alkali solu- } \\
\text { bility and antimicrobial properties. }\end{array}$ & [126] \\
\hline $\begin{array}{l}\text { Medicine/ } \\
\text { Health }\end{array}$ & $\begin{array}{l}\text { Drug delivery systems and ad- } \\
\text { ditives in pharmaceuticals }\end{array}$ & $\begin{array}{l}\text { Has antiseptics nature, kills germs and does } \\
\text { not immune to corrode by body tissue and } \\
\text { fluids. }\end{array}$ & $\begin{array}{l}{[69,84} \\
125,127 \\
128]\end{array}$ \\
\hline Food & $\begin{array}{l}\text { Additives, Beverages, Baked } \\
\text { items, Dairy Items, Chocolates } \\
\text { etc }\end{array}$ & $\begin{array}{l}\text { Provides whiteness and used as a coloring } \\
\text { agent. }\end{array}$ & $\begin{array}{l}{[81,86,} \\
87]\end{array}$ \\
\hline Environment & Waste water treatment & $\begin{array}{l}\text { Has strong photo-catalyst property, prevents } \\
\text { the bacteria to reproduce and causes the } \\
\text { organism degradation. }\end{array}$ & {$[81,90]$} \\
\hline
\end{tabular}


which increases their importance in the production of chemical fibers, printing ink, self-cleaning glass and ceramics [69]. To achieve the opaqueness, NTPs are also used in paper production and food packaging materials [89]. NTPs are also used in antimicrobial applications as well as in air and water purification [79]. Use of NTPs is helpful environmentally as it is a strong photo-catalyst; it can be used to break down complex and harmful organic matters and to kill germs. It can also prevent the bacteria to reproduce and is used as an antiseptic $[18,90]$.

Use of nano NTPs as antifogging agent is also reported due to its extraordinary cleansing properties [81]. NTPs in lambda probes of vehicles is gaining a lot of attention. As it can ensure proper fuel burning and can reduce vehicle emissions leading to clean environment [91]. Efforts are made to remove excess of nitrogen dioxide from environment by using their catalytic properties [69]. Due to higher solar radiation absorption rate, these particles can also be used as thermal and solar photovoltaics to save energy [92]. Properties like good strength, low density, high heat of reaction and corrosion resistance, make the NTPs an excellent materials to be utilized in various industries [93].

Traditional techniques like air purifiers, rather than completely eliminating, transfer the contaminants to another phase: A good method to de-pollute air is to incorporate a photo-catalytic material in the building materials like concrete and mortars [94]. Large surfaces of building materials are often illuminated with either sunlight or electrical lights; the building materials become self-cleaning. Along with cementitious materials, the layers of photocatalytic material may be deposited on glass panes to make them self-cleaning.

NTPs are well-known photo-catalyst that are used for many anti-pollution activities [19]. NTPs possess photo-catalytic properties because they are able to absorb energy from light, and then utilize it to catalyze the degradation of organic particles and the oxidation of some inorganic pollutants like nitrogen oxides from car exhausts [95]. Being nontoxic, stable and available in huge amounts are the additional qualities that make titania a popular photocatalytic material [20]. Among many photo-catalysts, titania is reported to have the most efficient photo-activity [78]. Surfaces containing NTPs are in practice in various civil engineering fields e.g. in buildings concrete blocks, plasters, windows and ceramic tiles and in roads in the production of asphalt and road signs [7,96-98]. A brief list of industrial applications of NTPs is presented in Table 2.

\section{RELATED HEALTH CONCERNS OF NTPS}

Nanomaterial means a natural, incidental or manufactured material, containing particles in an unbound state or as an aggregate or agglomerate; where $50 \%$ or more of the particles in the number size distribution have one or more external dimensions in the size range of $1-100 \mathrm{~nm}$ [80]. Now days, there is growing trend to use nano/micro materials in all fields of science and technology due to their strong capability of modifying the physical, mechanical properties and producing multifunctional characteristics [99-102]. These nano particles due to their smaller size possess very high penetration capability into the living cells that may produce harmful effects. Conventionally, nano titania particles are considered as low-toxic; however, concerns have been shown on the exposure to NTPs due to high activity and large surface to mass ratio [103]. A lot of researchers reported the health concerns related to NTPs in a very detailed manner $[69,104-106]$; here a very brief introduction is given.

On the basis of the experimental animal inhalation studies, NTPs are classified as "possible carcinogenic to humans" by the International Agency for Research on Cancer $[84,107]$. It has been reported that NTPs may cause mild eye irritation; repeated large dosages into the stomach result in some adverse effects to the liver and brain; Consumption of food containing NTPs may cause Crohn's disease (an inflammatory bowel disease (IBD)) $[108,109]$. Large quantities inhalation may lead to inflammation and asthma [110,111]. Dermal absorption can be an effective way through which NTPs can enter into human body. Sunscreens and other cosmetic creams can be the source for dermal absorption. However, literature shows that stratum corneum (layer on human skin) prevents the ingress of inorganic particles into human body [2,69]. The superoxide oxygen radicals, Eq. (2), is reported to cause significant damage to DNA [112]. Moreover, cells damage, cellular malfunction and change in proteins amount were also reported by researchers $[82,113,114]$. NTPs generated reactive oxygen species and oxidative stress, therefore can be considered as toxic $[115,116]$. Oxidative stress can cause different heart problems and can lead to heart failure [80]. Breathing in large quantities of NTPs over a long period of time may cause toxicity; a study on mice has suggested that low dose (200 $\mathrm{mg} / \mathrm{kg}$ of body weight (bw)) has no noticeable effect on the reproductive systems, but high-dose (500 $\mathrm{mg} / \mathrm{kg} \mathrm{bw}$ ) may significantly reduce their sperm 
count and function [117]. Lung and liver tumors were also reported in animals, which were exposed to high concentrations of NTPs [118-120]. In marine organisms NTPs affected the immune and digest gland function [121]. NTPs used in surface coatings are not expected to cause harmful effects to workers if the airborne concentrations be kept below some exposure limit over a period of eight hours. The National Institute for Occupational Safety and Health (NIOSH) in USA has proposed the permissible exposure level (PEL) of $1.5 \mathrm{mg} / \mathrm{m}^{3}$ and a recommended exposure level (REL) of $0.1 \mathrm{mg} / \mathrm{m}^{3}$ [122].

\section{CONCLUSIONS}

Although the use of nano titania particles is increasing rapidly all over the world. However, it has generated some serious health concerns not only for human but for other living organisms as well. Because of growing applications and large productions, release of NTPs is huge in soil and water bodies. Therefore, it may cause serious threats to human health and ecosystem. Until relevant toxicological and human exposure data that would enable reliable risk assessment are obtained, NTPs should be used with great care.

\section{REFERENCES}

[1] L. Zhang, R. Dillert, D. Bahnemann and M. Vormoor // Energy Environ. Sci. 5 (2012) 7491.

[2] S. Banerjee, D.D. Dionysiou and S.C. Pillai // Appl. Catal. B Environ. 176-177 (2015) 396.

[3] R. Benedix, F. Dehn, J. Quaas and M. Orgass // Lacer. 3 (2000) 157.

[4] R. Bott, Applications of Titanium Dioxide Photocatalysis to Construction Materials (Springer, Netherlands, Dordrecht, 2011).

[5] A.M.A. Mohamed, A.M. Abdullah and N.A. Younan // Arab. J. Chem. 8 (2015) 749.

[6] P. Ragesh, V. Anand Ganesh, S. V. Nair and A. S. Nair // J. Mater. Chem. A. 2 (2014) 14773.

[7].J. Bogdan, A. Jackowska-Tracz, J. Zarzyńska and J. Pławińska-Czarnak // Nanoscale Res. Lett. 10 (2015) 57.

[8] C. Mendoza, A. Valle, M. Castellote, A. Bahamonde and M. Faraldos // Appl. Catal. B Environ. 178 (2015) 155.

[9] W. Shen, C. Zhang, Q. Li, W. Zhang, L. Cao and J. Ye // J. Clean. Prod. 87 (2015) 762.

[10] A.M. Rashad // Rev. Adv. Mater. Sci. 40 (2015) 72.
[11] D.A.H. Hanaor and C.C. Sorrell // J. Mater. Sci. 46 (2011) 855.

[12] Y. Li, T.J. White and S.H. Lim // J. Solid State Chem. 177 (2004) 1372.

[13] A. Kolodziejczak-Radzimska and T. Jesionowski // Materials (Basel) 7 (2014) 2833.

[14] J. Yang, J. Zhang, L. Zhu, S. Chen, Y. Zhang, Y. Tang, Y. Zhu and Y. Li // J. Hazard. Mater. 137 (2006) 952.

[15] L. Znaidi // Mater. Sci. Eng. B Solid-State Mater. Adv. Technol. 174 (2010) 18.

[16] A. Mamalis, L.O. Vogtländer and A. Markopoulos // Precis. Eng. 28 (2004) 16.

[17] B. Duymaz, Z.V. Yigit, M.G. Şeker and F. Dündar // Acta Phys. Pol. A. 129 (2016) 872.

[18] J.C. Yu, H.Y. Tang, J. Yu, H.C. Chan, L. Zhang, Y. Xie, H. Wang and S.P. Wong // J. Photochem. Photobiol. A 153 (2002) 211. papers2://publication/uuid/7A82B577-D1D046ED-9247-119953269B64.

[19] D.M. Tobaldi, R.C. Pullar, A.F. Gualtieri, G. Otero-Irurueta, M.K. Singh, M.P. Seabra and J.A. Labrincha // J. Solid State Chem. 231 (2015) 87.

[20] S. Segota, L. Curkovic, D. Ljubas, V. Svetlicic, I.F. Houra and N. Tomasic // Ceram. Int. 37 (2011) 1153.

[21] T. Kemmitt, N.I. Al-Salim, J. Lian, V.B. Golovko and J.Y. Ruzicka // Curr. Appl. Phys. 13 (2013) 142.

[22] N.R. Mathews, E.R. Morales, M.A. CortesJacome and J.A. Toledo Antonio // Sol. Energy 83 (2009) 1499.

[23] X. Chen and S.S. Mao // Chem. Rev. 107 (2007) 2891.

[24] S. Sahni, S.B. Reddy and B.S. Murty // Mater. Sci. Eng. A 452-453 (2007) 758.

[25] L. Bergamonti, I. Alfieri, A. Lorenzi, A. Montenero, G. Predieri, R. Di Maggio, F. Girardi, L. Lazzarini and P.P. Lottici // J. Sol-Gel Sci. Technol. 73 (2015) 91.

[26] X. Ding and X. Liu // Mater. Sci. Eng. A 224 (1997) 210.

[27] S. Winardi, R.R. Mukti, K.N.P. Kumar, J. Wang, W. Wunderlich and T. Okubo // Langmuir 26 (2010) 4567.

[28] M. Barmala, A.Z. Moghadam and M.R. Omidkhah // J. Cent. South Univ. 23 (2016) 1066.

[29] M. Cargnello, T.R. Gordon and C.B. Murray // Chem. Rev. 114 (2014) 9319. 
[30] V. Vergaro, E. Aldieri, I. Fenoglio, A. Marucco, C. Carlucci and G. Ciccarella // Toxicol. Vitr. 34 (2016) 171.

[31] M. Niederberger, M.H. Bartl and G.D. Stucky // J. Am. Chem. Soc. 124 (2002) 13642.

[32] M. Niederberger, M.H. Bartl and G.D. Stucky // Chem. Mater. 14 (2002) 4364.

[33] G.V. Jensen, M. Bremholm, N. Lock, G.R. Deen, T.R. Jensen, B.B. Iversen, M. Niederberger, J.S. Pedersen and H. Birkedal // Chem. Mater. 22 (2010) 6044.

[34] A. Aboulaich, B. Boury and P.H. Mutin // Chem. Mater. 22 (2010) 4519.

[35] W. Wunderlich // Metals (Basel). 4 (2014) 410.

[36] W. Wunderlich, K.V. Baiju, S. Winardi and R.R. Mukti // Mater. Today Proc. 3 (2016) 662.

[37] M. Wu, G. Lin, D. Chen, G. Wang, D. He, S. Feng and R. Xu // Chem. Mater. 14 (2002) 1974.

[38] N. Watanabe, T. Kaneko, Y. Uchimaru, S. Yanagida, A. Yasumori and Y. Sugahara // CrystEngComm. 15 (2013) 10533.

[39] B. Li, Y. Xie, J. Huang and Y. Qian // Adv. Mater. 11 (1999) 1456.

[40] Y. Wu, H.-M. Liu, B.-Q. Xu, Z.-L. Zhang and D.-S. Su // Inorg. Chem. 46 (2007) 5093.

[41] Z. Lin, J.J. Cai, L.E. Scriven and H.T. Davis // J. Phys. Chem. 98 (1994) 5984.

[42] T. Li, J. Moon, A.A. Morrone, J.J. Mecholsky, D.R. Talham and J.H. Adair // Langmuir. 15 (1999) 4328.

[43] D. Zhang, L. Qi, J. Ma and H. Cheng // J. Mater. Chem. 12 (2002) 3677.

[44] D. Kuang, A. Xu, Y. Fang, H. Ou and H. Liu // J. Cryst. Growth 244 (2002) 379.

[45] X. Ju, P. Huang, N. Xu and J. Shi // J. Memb. Sci. 202 (2002) 63.

[46] L. Qi, J. Ma, H. Cheng and Z. Zhao // J. Phys. Chem. B 101 (1997) 3460.

[47] H. Sakai, H. Kawahara, M. Shimazaki and M. Abe // Langmuir 14 (1998) 2208.

[48] M. Wu, J. Long, A. Huang, Y. Luo, S. Feng and R. Xu // Langmuir 15 (1999) 8822.

[49] R. Sharma, R. Shaw, S. Tiwari and S. Tiwari // ACS Sustain. Chem. Eng. 3 (2015) 2796.

[50] E.M. van der Merwe, C.L. Mathebula and L.C. Prinsloo // Powder Technol. 266 (2014) 70.

[51] P. Hesemann, T. Nguyen and S. Hankari // Materials (Basel) 7 (2014) 2978.
[52] J.R. McCormick, B. Zhao, S.A. Rykov, H. Wang and J.G. Chen // J. Phys. Chem. B 108 (2004) 17398.

[53] M. Liberini, G. De Falco, F. Scherillo, A. Astarita, M. Commodo, P. Minutolo, A. D'Anna and A. Squillace // Thin Solid Films 609 (2016) 53.

[54] Y.K. Kho, W.Y. Teoh, L. Mädler and R. Amal // Chem. Eng. Sci. 66 (2011) 2409.

[55] J.M. Mäkelä, S. Hellstén, J. Silvonen, M. Vippola, E. Levänen and T. Mäntylä // Mater. Lett. 60 (2006) 530.

[56] G. De Falco, M. Commodo, P. Pedata, P. Minutolo and A. D'Anna // Chem. Eng. Trans. 47 (2016) 439.

[57] M. Gericke and A. Pinches // Hydrometallurgy 83 (2006) 132.

[58] A.R. Shahverdi, A. Fakhimi, H.R. Shahverdi and S. Minaian // Nanomedicine Nanotechnology, Biol. Med. 3 (2007) 168.

[59] N. Mokhtari, S. Daneshpajouh, S. Seyedbagheri, R. Atashdehghan, K. Abdi, S. Sarkar, S. Minaian, H.R. Shahverdi and A.R. Shahverdi // Mater. Res. Bull. 44 (2009) 1415.

[60] A.R. Shahverdi, S. Minaeian, H.R. Shahverdi, H. Jamalifar and A.-A. Nohi // Process Biochem. 42 (2007) 919.

[61] L. Du, H. Jiang, X. Liu and E. Wang // Electrochem. Commun. 9 (2007) 1165.

[62] M.F. Lengke, M.E. Fleet and G. Southam // Langmuir 23 (2007) 8982.

[63] N. Saifuddin, C.W. Wong and A.A.N. Yasumira // E-Journal Chem. 6 (2009) 61.

[64] M. Agnihotri, S. Joshi, A.R. Kumar, S. Zinjarde and S. Kulkarni // Mater. Lett. 63 (2009) 1231.

[65] S.A. Kumar, Y.-A. Peter and J.L. Nadeau // Nanotechnology 19 (2008) 495101.

[66] K. Kathiresan, S. Manivannan, M.A.A. Nabeel and B. Dhivya // Colloids Surfaces B Biointerfaces 71 (2009) 133.

[67] R. Varshney, A.N. Mishra, S. Bhadauria and M.S. Gaur // Dig. J. Nanomater. Bistructures 4 (2009) 349.

[68] K. Prasad, A.K. Jha and A.R. Kulkarni // Nanoscale Res. Lett. 2 (2007) 248.

[69] K. Banerjee and P. Thiagarajan // Nanosci. Nanotechnology-Asia 4 (2014) 132.

[70] A.K. Jha, K. Prasad and K. Prasad // Biochem. Eng. J 43 (2009) 303.

[71] A.K. Jha, K. Prasad and A.R. Kulkarni // Colloids Surfaces B Biointerfaces 71 (2009) 226. 
[72] X. Zhang, S. Yan, R.D. Tyagi and R.Y. Surampalli // Chemosphere 82 (2011) 489.

[73] J. Cui, W. He, H. Liu, S. Liao and Y. Yue // Colloids Surfaces B Biointerfaces 74 (2009) 274.

[74] V. Bansal, D. Rautaray, A. Bharde, K. Ahire, A. Sanyal, A. Ahmad and M. Sastry // J. Mater. Chem. 15 (2005) 2583.

[75] M.M. Haque, D. Bahnemann and M. Muneer // Photocatalytic Degrad. Org. Pollut. Mech. Kinet 3 (2012) 294.

[76] Y.-H. Tseng and B.-K. Huang // Int. J. Photoenergy 2012 (2012) 1.

[77] S. Daviđsdóttir, J. Soyama, K. Dirscherl, S. Canulescu and J. Schou // Eur. Corros. Congr. 2011 (2011) 1.

[78] K. Hashimoto, H. Irie and A. Fujishima // Jpn. J. Appl. Phys. 44 (2005) 8269.

[79] R. Landsiedel, L. Ma-Hock, A. Kroll, D. Hahn, J. Schnekenburger, K. Wiench and W. Wohlleben // Adv. Mater. 22 (2010) 2601.

[80] H. Shi, R. Magaye, V. Castranova and J. Zhao // Part. Fibre Toxicol. 10 (2013) 15.

[81] A. Weir, P. Westerhoff, L. Fabricius, K. Hristovski and N. von Goetz // Environ. Sci. Technol. 46 (2012) 2242.

[82] J. Sund, J. Palomäki, N. Ahonen, K. Savolainen, H. Alenius and A. Puustinen // J. Proteomics 108 (2014) 469.

[83] C. Della Torre, F. Buonocore, G. Frenzilli, S. Corsolini, A. Brunelli, P. Guidi, A. Kocan, M. Mariottini, F. Mottola, M. Nigro, K. Pozo, E. Randelli, M.L. Vannuccini, S. Picchietti, M. Santonastaso, V. Scarcelli, S. Focardi, A. Marcomini, L. Rocco, G. Scapigliati and I. Corsi // Environ. Pollut. 196 (2015) 185.

[84] M. Skocaj, M. Filipic, J. Petkovic and S. Novak // Radiol. Oncol. 45 (2011) 227.

[85] E.G. Zemtsova, P.E. Morozov, R.Z. Valiev, J. Orekhov and V.M. Smirnov // Rev. Adv. Mater. Sci. 45 (2016) 59.

[86] U. Diebold // Appl. Surf. Sci. 48 (2003) 53.

[87] J. Wang, G. Zhou, C. Chen, H. Yu, T. Wang, Y. Ma, G. Jia, Y. Gao, B. Li, J. Sun, Y. Li, F. Jiao, Y. Zhao and Z. Chai // Toxicol. Lett. 168 (2007) 176.

[88] S. Watson, D. Beydoun and R. Amal // J. Photochem. Photobiol. A Chem. 148 (2002) 303.

[89] S. Mozia // Catal. Today 156 (2010) 198.

[90] S.K. Das, A.R. Das and A.K. Guha // Langmuir 25 (2009) 8192.

[91] M.O.B. Gratzel // Nature 354 (1991) 56.
[92] C.R. Kothapalli and A. Ramamurthi // Acta Biomater. 5 (2009) 541.

[93] L. Vinet and A. Zhedanov // Fuel 181 (2010) 785.

[94] D. Sannino, V. Vaiano, G. Sarno and P. Ciambelli, In: Chem. Eng. Trans. (2013) p. 355.

[95] Y. Hendrix, A. Lazaro, Q. Yu and J. Brouwers // World J. Nano Sci. Eng. 5 (2015) 161.

[96] T.M. Mendes, D. Hotza and W.L. Repette // Rev. Adv. Mater. Sci. 40 (2015) 89.

[97] A. Khitab and M.T. Arshad // Rev. Adv. Mater. Sci. 38 (2014) 181.

[98] A. Khitab, W. Anwar, I. Mansouri, M.K. Tariq and I. Mehmood // Rev. Adv. Mater. Sci. 42 (2015) 20.

[99] M. Usman, I.-H. Kim and H.-J. Jung // AIP Adv. 6 (2016) 55027.

[100] R.A. Khushnood, S. Ahmad, P. Savi, J.-M. Tulliani, M. Giorcelli and G.A. Ferro // Constr. Build. Mater. 85 (2015) 208.

[101] S. Ahmad, R.A. Khushnood, P. Jagdale, J.-M. Tulliani and G.A. Ferro // Mater. Des. 76 (2015) 223.

[102] A.S. Afify, S. Ahmad, R.A. Khushnood, P. Jagdale and J.-M. Tulliani // Sensors Actuators B Chem. 239 (2017) 1251.

[103] N.Y. Mar // Prospects 35 (2005) 331.

[104] C. a a a Schulz, H. Hohenberg, F. Pflucker, E. Gartner, T. Will, S. Pfeiffer, R. Wepf, V. Wendel, H. Gers-Barlag and K.-P. Wittern // Adv. Drug Deliv. Rev. 54 (2002) 157. www.elsevier.com.

[105] I. lavicoli, V. Leso and A. Bergamaschi // J. Nanomater. 2012 (2012) 1.

[106] J. Paunovic, D. Vucevic, T. Radosavljevic, S. Pantic, D. Nikolovski, S. Dugalic and I. Pantic // Rev. Adv. Mater. Sci. 49 (2017) 123.

[107] B.R. Fonslow, B.D. Stein, K.J. Webb, T. Xu, J. Choi, S. K. Park and J.R. Yates // Nat. Methods 10 (2013) 54.

[108] B. Fadeel and A.E. Garcia-Bennett // Adv. Drug Deliv. Rev. 62 (2010) 362.

[109] M.C.E. Lomer, R.P.H. Thompson and J.J. Powell // Proc. Nutr. Soc. 61 (2002) 123.

[110] S. Hussain, J.A.J. Vanoirbeek, K. Luyts, V. De Vooght, E. Verbeken, L.C.J. Thomassen, J.A. Martens, D. Dinsdale, S. Boland, F. Marano, B. Nemery and P.H.M. Hoet // Eur. Respir. J. 37 (2011) 299. 
[111] S. Jonasson, A. Sa Gustafsson, B. Koch and A. Bucht // Inhal Toxicol. 25 (2013) 1091.

[112] J.R. Gurr, A.S.S. Wang, C.H. Chen and K.Y. Jan // Toxicolog 213 (2005) 66.

[113] A. D'Agata, S. Fasulo, L.J. Dallas, A.S. Fisher, M. Maisano, J.W. Readman and A.N. Jha // Nanotoxicology 8 (2014) 549.

[114] E. Fabian, R. Landsiedel, L. Ma-Hock, K. Wiench, W. Wohlleben and B. van Ravenzwaay // Arch. Toxicol. 82 (2008) 151.

[115] J.-B. Park // Exp. Mol. Med. 35 (2003) 325.

[116] K. Bhattacharya, M. Davoren, J. Boertz, R.P. Schins, E. Hoffmann and E. Dopp // Part. Fibre Toxicol. 6 (2009) 17.

[117] L.L. Guo, X.H. Liu, D.X. Qin, L. Gao, H.M. Zhang, J.Y. Liu and Y.G. Cui // Zhonghua Nan Ke Xue. 15 (2009) 517.

[118] E. Bermudez, J.B. Mangum, B.A. Wong, B. Asgharian, P.M. Hext, D.B. Warheit and J.I. Everitt // Toxicol. Sci. 77 (2004) 347.

[119] B. Sha, W. Gao, S. Wang, F. Xu and T. Lu // Compos. Part B Eng. 42 (2011) 2136.

[120] F. Pflücker, V. Wendel, H. Hohenberg, E. Gärtner, T. Will, S. Pfeiffer, R. Wepf and H. Gers-Barlag // Skin Pharmacol. Appl. Skin Physiol. 14 (2001) 92.

[121] C. Barmo, C. Ciacci, B. Canonico, R. Fabbri, K. Cortese, T. Balbi,
A. Marcomini, G. Pojana, G. Gallo and L. Canesi // Aquat. Toxicol. 132-133 (2013) 9.

[122] J. Davis, A. Wang and J.A. Shtakin, Nanomaterial Case Studies: Nanoscale Titanium Dioxide in Water Treatment and in Topical Sunscreen (U.S. Environmental Protection Agency, Washington, DC, EPA/600/R-09/057F, 2010).

[123] J. Lim, J. Pyo, D. Jung, H.-S. Jung and J.-K. Lee // J. Sol-Gel Sci. Technol. 79 (2016) 89.

[124] L. Li, X. Sun, Y. Yang, N. Guan and F. Zhang // Chem. - An Asian J. 1 (2006) 664.

[125] U.S. Food and Drug Administration, Listing of color additives exempt from certification in: Title 21 - Food and Drugs (Code of Federal Regulations 73.575, 1996).

[126] M. Montazer and E. Pakdel // J. Photochem. Photobiol. C Photochem. Rev. 12 (2011) 293.

[127] D. Drobne, A. Jemec and Ž. Pipan Tkalec // Environ. Pollut. 157 (2009) 1157.

[128] G.M. Lanza, P.M. Winter, S.D. Caruthers, M.S. Hughes, T. Cyrus, J.N. Marsh, A.M. Neubauer, K.C. Partlow and S. A Wickline // Nanomedicine (Lond) 1 (2006) 321. 